\title{
Kontaktörlerde Anahtarlama Sayısının Elektrik Ark Erozyonuna ve Kontaktör Yüzey Hasarlarına Etkileri
}

\author{
Mustafa Nuri Sav ${ }^{1}$, Sinan Fidan ${ }^{2 *}$, Satılmıș Ürgün ${ }^{3}$ \\ ${ }^{1}$ Kocaeli Üniversitesi, Fen Bilimleri Enstitüsü, Havacılık Bilimi ve Teknolojileri Bölümü, Kocaeli, Türkiye, (ORCID: 0000-0002-4495-5883), \\ mustafanurisav@gmail.com \\ 2* Kocaeli Üniversitesi, Havacılık ve Uzay Bilimleri Fakültesi, Uçak Gövde Motor Bakımı Bölümü, Kocaeli, Türkiye (ORCID: 0000-0003-4385-4981), \\ sfidan@kocaeli.edu.tr \\ ${ }^{3}$ Kocaeli Üniversitesi, Havacılık ve Uzay Bilimleri Fakültesi, Havacılık Elektrik ve Elektroniği Bölümü, Kocaeli, Türkiye (ORCID: 0000-0003-3889-6909), \\ urgun@kocaeli.edu.tr
}

(İlk Geliş Tarihi 01 Haziran 2021 ve Kabul Tarihi 10 Kasım 2021)

(DOI: 10.31590/ejosat.946690)

ATIF/REFERENCE: Sav, M.N., Fidan, S. \& Ürgün, S. (2021). Kontaktörlerde Anahtarlama Sayısının Elektrik Ark Erozyonuna ve Kontaktör Yüzey Hasarlarına Etkileri. Avrupa Bilim ve Teknoloji Dergisi, (27), 723-734.

$\ddot{\mathbf{O z}}$

Elektrik ark erozyonu, elektriksel devrelerin anahtarlama görevi yapan elemanlarında ortaya çıkabilen önemli hasar türlerinden bir tanesidir. Hassas elektrik devrelerinin kararlı bir çalışma gerçekleştirebilmesi için, ark erozyonuna bağlı yüzey hasarlarının mümkün olduğunca az olması istenir. Ark erozyonu, kontaktör servis ömrünü kısaltıcı etkilere yol açar. Kontaktör ömrünü uzatabilmek için yapılan çalışmalar ark erozyonu miktarını azaltmak veya ark şiddetini düşürmek üzerine yoğunlaşmıştır. Ark erozyonunun gerçekleşme karakteristiği, farklı disiplinlerin çalışma alanı olan birbirinden bağımsız birçok etken tarafından belirlenmektedir. Bu çalışmada mekanik, metalurjik ve elektrik olmak üzere farklı disiplinlerden hibrit bir araştırma yöntemiyle, Ag-Ni kontaktörlerin 12VDC 5A yük altında rezistif bir devrede farklı çevrimler sayılarında gözlemlenen deformasyonları incelenmiştir. Deneysel verilerden elde edilen sonuçlar literatürdeki çalışmalarla karşılaştırmalı olarak değerlendirilmiş; mekanik, metalurjik ve elektriksel parametrelerin elektrik ark erozyonuyla beraber kontaktör yüzeylerinde ortaya çıkardığı pürüzlülük mekanizmaları ortaya konulmuştur.

\section{The Effects of the Number of Switching in Contactors on Electric Arc Erosion and Contactor Surface Damages}

\begin{abstract}
Electric arc erosion is one of the important types of damage that can occur in the switching elements of electrical circuits. In order for sensitive electrical circuits to perform stable operation, surface damage due to arc erosion is desired to be as little as possible. Arc erosion leads to effects that shorten the contactor service life. Studies conducted to extend the lifetime of the contactor have focused on reducing the amount of arc erosion or decreasing the arc intensity. The occurrence characteristic of arc erosion is determined by many independent factors that are the field of study of different disciplines. In this study, the deformations of Ag-Ni contactors in a resistive circuit under $12 \mathrm{VDC} 5 \mathrm{~A}$ load at different number of cycles were investigated using a hybrid research method from different disciplines including mechanical, metallurgical and electrical. The results obtained from the experimental data were evaluated in comparison with the studies in the literature; Roughness mechanisms caused by mechanical, metallurgical, and electrical parameters along with electric arc erosion on contactor surfaces have been revealed.
\end{abstract}

Keywords: Arc erosion, Number of switching, Surface roughness.

* Sorumlu Yazar: $\underline{\text { sfidan@ @ocaeli.edu.tr }}$ 


\section{Giriş}

Kontaktörler elektrik devrelerinde anahtarlama görevi üstlenen elemanlarda iletimin sağlanması veya kesilmesi için birbiri ile temas eden veya ayrılan parçalardır. Birçok uygulamada elektrik devrelerinin ömrü, hassaslığı ve kararlılığ kritik öneme sahiptir. Uygulamalardaki ömür, hassaslık ve kararlılığın belirlenmesinde önemli parametrelerden biri de kontakların işlevlerini ne kadar süre boyunca düzgün bir şekilde yerine getirebilecekleridir(Swingler \& McBride John W., 2008),(Jemaa et al., 1998). Yapılan çalışmalar ortaya koymuştur ki kontaktörler kullanım ömürleri sırasında çeşitli deformasyon mekanizmalarından etkilenmektedir. Elektrik ark erozyonu bu deformasyon mekanizmaları arasında belirgin bir şekilde öne çıkan ve incelenmeye değer hasarlar birakan bir hasar mekanizmasıdır.

Elektrik arkı, kontak yüzeyi arasındaki ortamın iletkenlik direncinin aşılması sonucu meydana gelen bir elektrik sıçramasıdır. Ark kontaktörler arasında açılış veya kapanış sırasında voltaj ve amper değerlerinin belirli bir minimum seviyesinde olduğunda meydana gelir (Xue Zhou et al., 2015). Elektrik ark1, plazma fazında meydana gelmektedir ve ark oluşumu sırasında ortamdaki gaz atomları pozitif yüklenerek katot yüzeyini bombardımana tutar. $\mathrm{Bu}$ yüklü gaz atomu bombardımanında katot yüzeyinden metal atomları kopmaya başlar ve anot yüzeyine doğru göç eder. Bir diğer mekanizma ise kontaktör yüzeylerinde meydana gelen 1sınma sonucu yüzeylerde ergimelerin oluşması temeline dayanır (Hwang et al., 2020). Makro ölçekte temas yüzeyi büyük görünse de dinamik temas noktaları malzemelerin yüzey pürüzlülügüünden dolayı çok daha düşüktür ve bu düşük temas yüzeyinden geçmeye çalışan elektrik akımı malzemenin direncinden kaynaklı lokal ısınmalara sebep olmaktadır. Bu 1sınmalar yüzeylerde sıvı metal havuzları oluşumuna sebep olabilir ve kontakların temastan sonra ayrılma sürecinde bu sıvı metal havuzları yüzey geriliminden kaynaklı iki kontak arasında sıvı metal köprüleri oluşturur. Bu köprülerin oluşumu sırasında ark oluşumu ile sıvı metal köprüleri patlar ve metal atomları pozitif yükle yüklenerek katot yüzeyine çökelir. Temel olarak elektrik ark erozyonunun gerçekleşmesinde evaporasyon ve sputtering mekanizmalarının etken olduğu bilinse de yapılan araştırmalar bu iki mekanizmanın dışında yüzeyde kaynaklanma, sıv1 metal transferi ve kopma gibi olayların gerçekleşebileceğini ortaya koymuştur (Abbaoui et al., 2006),(Lin et al., 2019; Wu et al., 2015),(Mützel \& Niederreuther, 2012).

$\mathrm{Bu}$ mekanizmalardan hangisinin gerçekleşeceğine ve erozyon olayının ne şiddette gerçekleşeceğine birçok faktör etki etmektedir. Bu etkenleri 3 temel başlıkta ele alabiliriz:

Elektriksel Parametreler

- $\quad$ Elektrik akımının türü (AC-DC)

- Yüklenme şekli (rezistif, kapasitif, indüktif)

- Akım ve gerilim şiddeti ve frekansı

Mekanik Faktörler

- Kontak geometrisi ve tasarımı

- Kinematik

- Anahtarlama düzenekleri

\section{Malzeme Özellikleri}

- Elektriksel ve 1sil iletkenlik

- Korozyon direnci

- $\quad$ Sertlik

- Ergime sicaklığ1 (Bıyık, 2015),(Hwang et al., 2020; Kharin et al., 2015),(Zhu et al., 2017)

Elektrik kontakları olarak kullanılan malzemeler genellikle gümüş veya bakır esaslı olup farklı özelliklerin geliştirildiği kompozitler olarak üretilmektedir. Yaygın kullanım şekilleri metal-metal takviyeli veya metal-metal oksit takviyeli yapılardır. Kullanılan esas bileşen iletkenlik özelliğinin ön plana çıktığı metal veya alaşımlar olarak seçilmektedir, genellikle $\mathrm{Ag}$ veya $\mathrm{Cu}$ tercih edilmekle beraber bazı çalışmalarda farklı metal alaşımları da kullanılmıştır. Metal matrise takviye fazı olarak kullanılacak ikinci bileşen ise oluşacak deformasyonlara karşı direnç oluşturması için tercih edilen W, Ni ve Ti gibi yüksek ergime sicaklıklarına sahip veya yüksek sertliğe sahip metaller veya metal oksit, karbür, borür, nitrür gibi yüksek sertlikteki takviye elemanlarıdır (Hu et al., 2016),(Cui et al., 2016).

Yapılan çalışmaların sonucuna göre ark erozyonunun farklı frekans değerlerinde farklı miktarlarda taşınım gösterdiği, düşük akım şiddetlerinde evaporasyon; yüksek akım şiddetlerinde sputter erozyonunun temel erozyon mekanizması olduğu, kontakları tutan kirişlerinin young modüllerinden kaynaklı açılış ve kapanış sırasındaki kinematiğin değiştiği ve bunun sonucunda farklı erozyon özellikleri gözlemlendiği ortaya çıkmıştır(Hwang et al., 2020; Xue Zhou et al., 2015). Deneysel çalışmaların yanı sıra simülasyon çalışmalarında ise elektrik ark enerjisinin malzeme taşınımı üzerine olan etkisi ortaya konulmuştur. Bu etki ark enerjisinin kontak yüzey sıcaklığını arttırdığını ve çok kısa bir sürede metalin kaynama sıcaklığını aştığını göstermektedir. $\mathrm{Bu}$ sırada ısınma ergime, kaynama, buharlaşma, sıçrama olaylarını katılaşma süreci takip etmektedir. Bu olaylar sırasında anot ve katot yüzeyleri farklı sıcaklık seviyelerine çıktığından dolayı farklı zamanlarda ergime ve katılaşma olayı gözlemlenmektedir. $\mathrm{Bu}$ farkın sonucunda anot ve katot yüzeylerinde farklı oranlarda farklı tiplerde erozyon oluşmaktadır(Cui et al., 2016; Rong et al., 2009; Tian et al., 2016; Xue Zhou et al., 2015).

$\mathrm{Bu}$ kadar geniş bir alan yelpazesine sahip olan elektrik ark erozyonuna dair Türkçe literatürde çok az sayıda kaynak bulunmaktadır. Yabancı kaynaklarda ise yapılan çalışmalar genellikle kütle taşınımı veya ark enerjisi üzerine yoğunlaşmıştır ve genellikle yüksek elektriksel değerlerde çalışılmıştır. $\mathrm{Bu}$ çalışmada 12V DC 5A değerlerinde Ag-Ni esaslı kontaktörlerde elektrik ark erozyonu davranışı incelenmiştir. $\mathrm{Bu}$ inceleme sırasında anahtarlama işleminde kapanış ve açılış süreleri, ark sırasında ark enerjileri ve ark süreleri hesaplanarak mukayese edilmiş ve numunelerde oluşan deformasyonlar birbirleri ile kıyaslanmıştır.

\section{Materyal ve Metot}

\subsection{Numunelerin Özellikleri}

$\mathrm{Bu}$ çalışmada Panasonic marka ALQ112 model röleler kullanılmıştır. Kullanılan rölelerin bilgileri firma ilgili veri sayfasında mevcuttur. $\mathrm{Bu}$ rölelerde $\mathrm{AgNi}$ kontaklar 
kullanılmaktadır. AgNi kontaklar yüksek iletkenlik özelliğine sahip düşük akım seviyelerinde kullanılmak için ideal kontaklardır (Jemaa et al., 1998). Şekil 1'de kullanılan rölenin bir görüntüsüne yer verilmiştir.

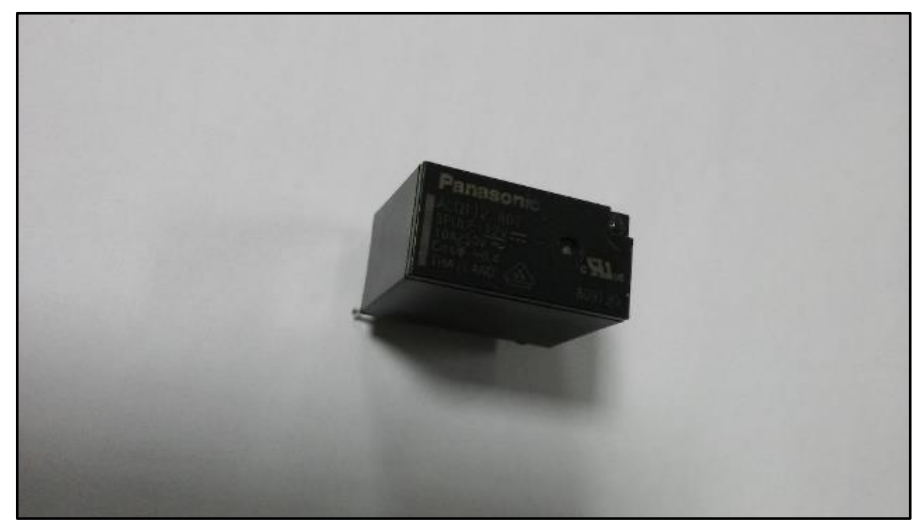

Şekil 1. Panasonic ALQ112 rölesinin dış görünüşü.

$\mathrm{Bu}$ rölelerin içerisinde ikisi sabit biri hareketli olmak üzere toplamda üç kontaktör bulunmaktadır. Bu kontaktörlerden hareketli olanın normal konumu Şekil 2'de görüldüğü üzere bir sabit kontaktörle sürekli kapalı kalacak şekilde ve diğer sabit kontaktörle ayrı duracak şekildedir. Bobinde oluşan manyetik kuvvet ile röle içerisinde harekete geçen bir metal parçaya bağlı olan kırmızı oklarla gösterilmiş polimer parça ileri doğru hareket ederek hareketli kontaktörü sabit kontaktörlerden kapalı olandan ayırarak açı olana temas ettirir. Bu çalışmada normal konumunda açık halde duran kontaktör kullanılmıştır. Normali kapalı olan sabit kontaktörün üzerinden herhangi bir akım geçirilmemiştir. Rölelerin içerisinde yaklaşık $0.5 \mathrm{~mm}$ çapında Ag-Ni kontaktörler kullanılmaktadır. Kullanılan bu kontaktörler sırası ile çevrim sayıları ve konumlarına göre 5S: 5000 çevrim sabit kontak, 5H: 5000 çevrim hareketli kontak, 10S: 10000 çevrim sabit kontak, 10H: 10000 çevrim hareketli kontak, 20S: 20000 çevrim sabit kontak: $20 \mathrm{H}$ : 20000 çevrim hareketli kontak olacak şekilde isimlendirilmiştir.

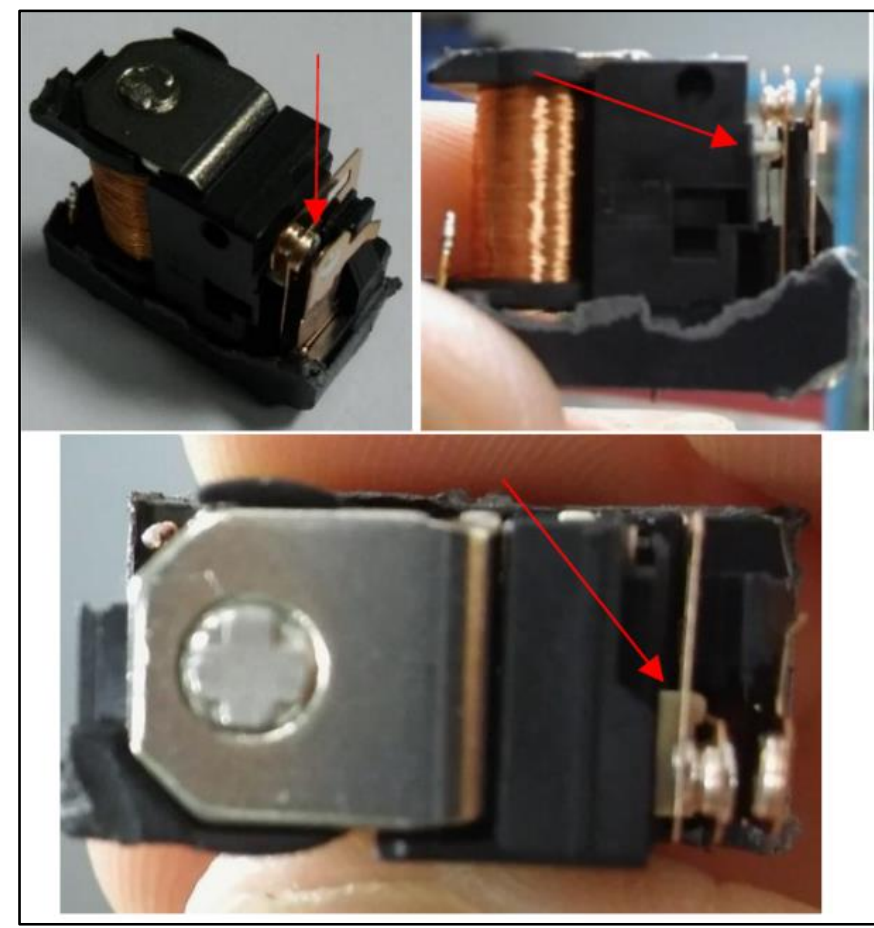

Şekil 2. Rölenin içyapısının farklı yönlerden fotoğrafları.

\subsection{Ark Erozyon Deneyi}

Ark erozyon deneyi için her bir çevrim 2,5 saniyede tamamlanıp bu sürenin içerisinde $100 \mathrm{~ms}$ boyunca devreden $12 \mathrm{~V}$ 5A DC akım geçirilmiştir. Bu çevrimlerin oluşturulması için kullanılan devre elemanları Şekil 3'te verilmiştir. Deney düzeneği rezistif yük olacak şekilde hazırlanmıştır. Giriş kısmında belirtildiği üzere devrenin rezistif, indüktif veya kapasitif olması ark sürecinde farklılıklara yol açmaktadır.

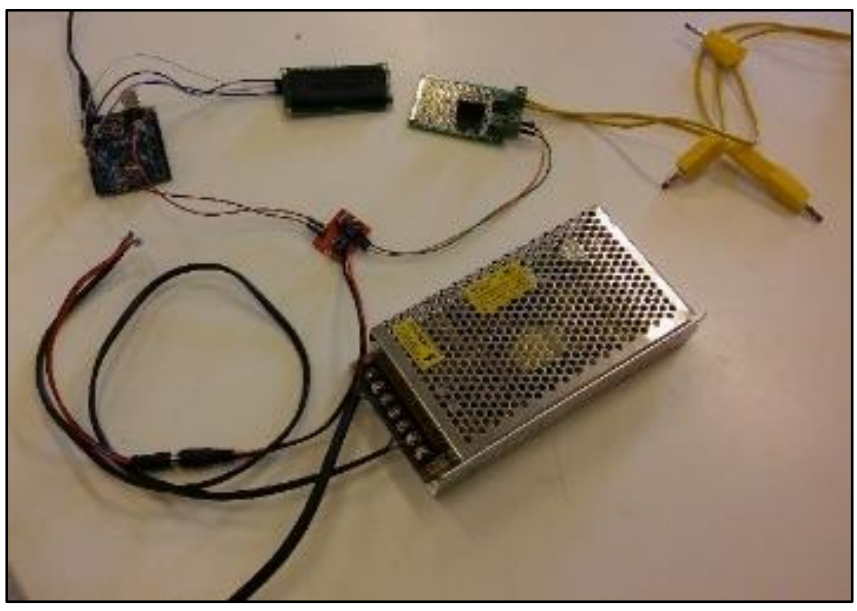

Şekil 3. Anahtarlama düzeneğinde kullanılan ekipmanlar.

Şekil 4'te gösterilen Lecroy Waverunner 6100A osiloskop kullanılarak deney sırasında elektriksel veriler anlık olarak gözlemlenerek kaydedilmiştir. Bu osiloskop ile anahtarlama sırasında akım ve gerilim değerlerindeki değişimi ve anahtarlama sırasındaki akım ve gerilimin yükseliş (rise time) ve düşüş (fall time) ve güç grafiklerindeki piklerin süreleri ölçülerek ark enerjileri hesaplanmıştır. Ark olayı bu açma kapama sırasında meydana gelmektedir ve yapılan çalışmalar ark süre ve enerjilerinin elektrik ark erozyonu ile taşınan malzeme arasında bir ilişki olduğunu ortaya koymuştur (Hu et al., 2016). 
Ark oluşumu için gerekli DC güç kaynağı Şekil 4'te gösterilen SAKO SK1731SL5A ve LeCroy WaveRunner 6000A osiloskop cihazı kullanılmıştır.

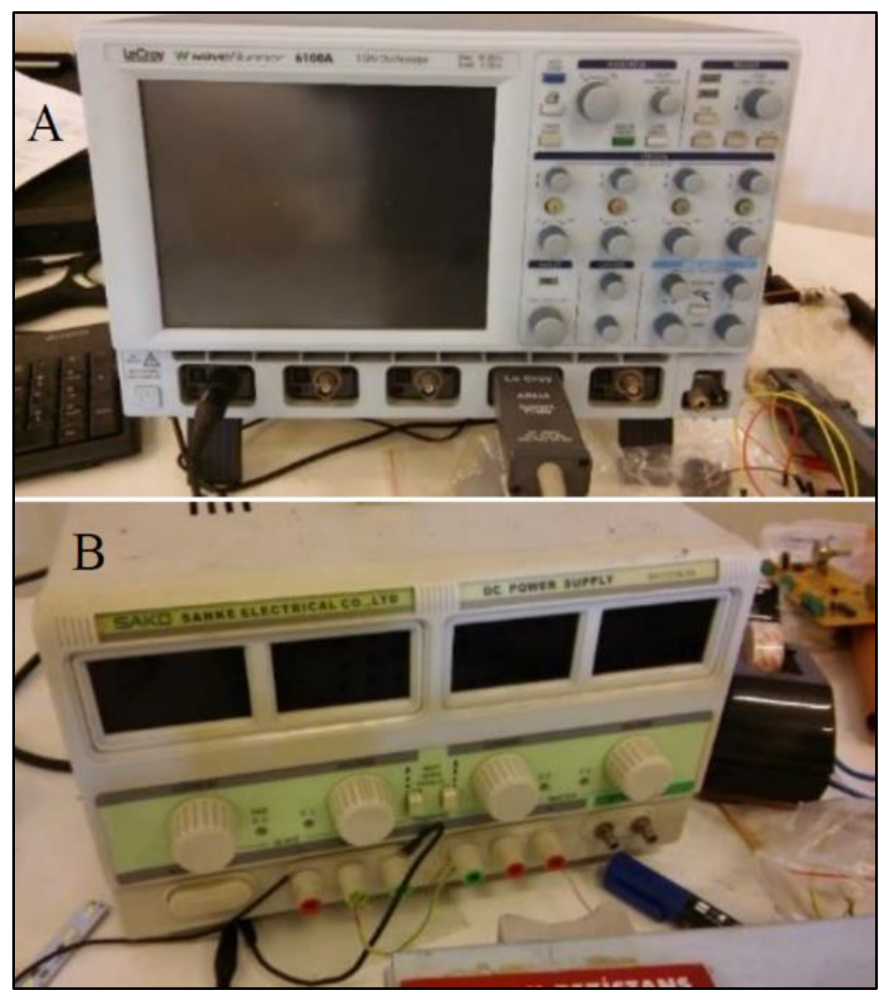

Şekil 4. Deney sırasında kullanılan a) Osiloskop b) DC güç kaynağ1.

Kullanılan osiloskop ile anahtarlama sırasında akım ve gerilim değerlerindeki değişimi; anahtarlama sırasındaki akım ile gerilimin yükseliş (rise time) ve düşüş (fall time) süreleri ölçülmüştür. Elde edilen veriler Curve Fitting kullanılarak grafik haline getirilmiştir. Daha önce belirtildiği üzere ark olayı bu açma kapama sırasında meydana gelmektedir ve bu süreler bize erozyonunun gerçekleştiği süre hakkında fikir vermektedir. Bu olayın gerçekleşmesi sırasında kontaklar birbirinden ayrılır ve potansiyel fark yükselir. Potansiyel farkın yükselmesi sırasında ark olayının gerçekleşmesi kaçınılmazdır. Ark olayı potansiyel fark ve akım grafiklerinden gözlemlenebileceği gibi güç grafiğindeki piklerle de tespit edilebilmektedir. Bu noktada ark enerjisinin hesaplanmasında akım, gerilim ve ark süresi değerlerinin kullanıldığı çeşitli formüller kullanılmaktadır(Jemaa et al., 1998)(Hu et al., 2016),(Liying et al., 2013),(Jing et al., 2011). Bu çalışmada akım ve gerilimin bir fonksiyonu olarak güç piklerinin alanı üzerinden ark enerjisi hesaplanmıştır.

Şekil 5 'te verilen grafiklerde kesim işleminden sonra ortaya çıkan piklerin kesimden sonra kontaklar arasında mikro-ark oluşumları gözlemlenmiştir. $\mathrm{Bu}$ olay düşük anahtarlama çevrimlerinden yüksek anahtarlama çevrimlerine kadar düzensiz aralıklarla olmaya devam etmiştir. Bu olayın gerçekleşmesine dair birçok sebep sunulabilir. Sebepler arasında; anahtarlama için kullanılan bobinde biriken indüktif yükün kesim sonrasında anlık manyetik anahtarlama düzeneğini harekete geçirmesi ve kontakların küçük bir hareket göstererek aradaki mesafenin değişmesiyle ortamın iletkenlik direncinin aşılması ile ark oluşumuna sebep olması veya anahtarlama süresince kontak yüzeylerinden buharlaşan metal atomları ile ortam atmosferinin karışımının iletkenlik değerinin ark oluşumuna sebep olması sayılabilir (Rong et al., 2009). Oluşan arkın indüktif olduğu çıkarımı kontaklar arasındaki mesafeden dolayı kesin olarak e-ISSN: 2148-2683 yapılabilir. Yapılan araştırmalara göre rezistif yükün ark mesafesinin $100 \mu \mathrm{m}$ uzunluğuna kadar gerçekleştiğini ve daha uzun boyda arkların indüktif yüklerle gerçekleştiğini ortaya koymuştur (Jemaa et al., 1998).

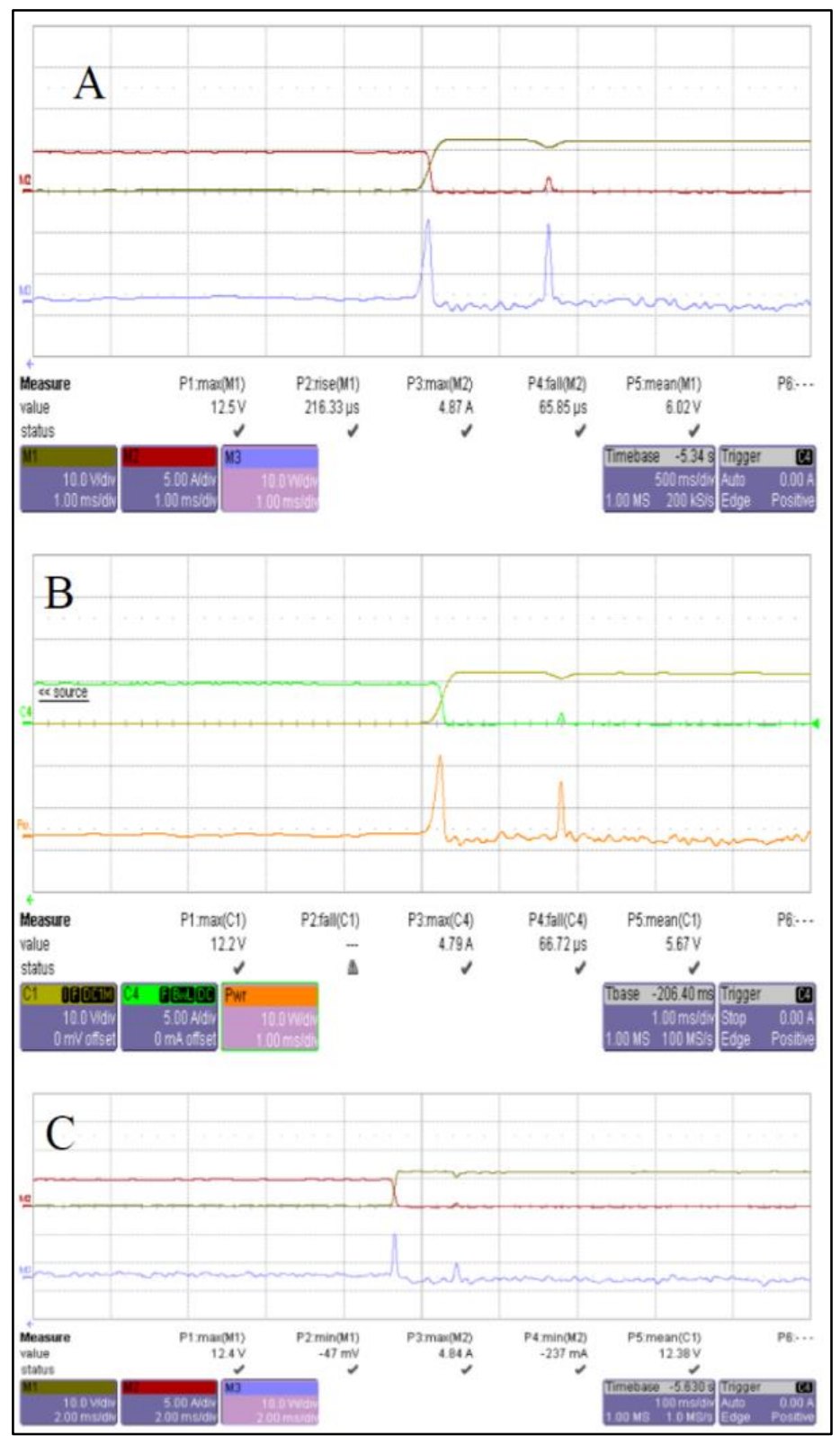

Şekil 5. A) 10000 B) 12000 C) 15000 çevrim sonrasında kesim esnasında akım gerilim ve güç grafikleri.

Şekil 6'da kontaktörlerin kapanması esnasında akım, gerilim ve güç grafiklerindeki dalgalanmanın başlangıcı ve anahtarlama sayılarının artıșı ile bu dalgalanmanın daha belirgin hale gelerek çift pik oluşturması görülmektedir. Oluşum düşük çevrimlerde görülmemektedir. Çevrim sayısı arttıkça belirgin hale gelmekte ve 10 bin anahtarlama ile gözlemlenmeye başlanmaktadır. 


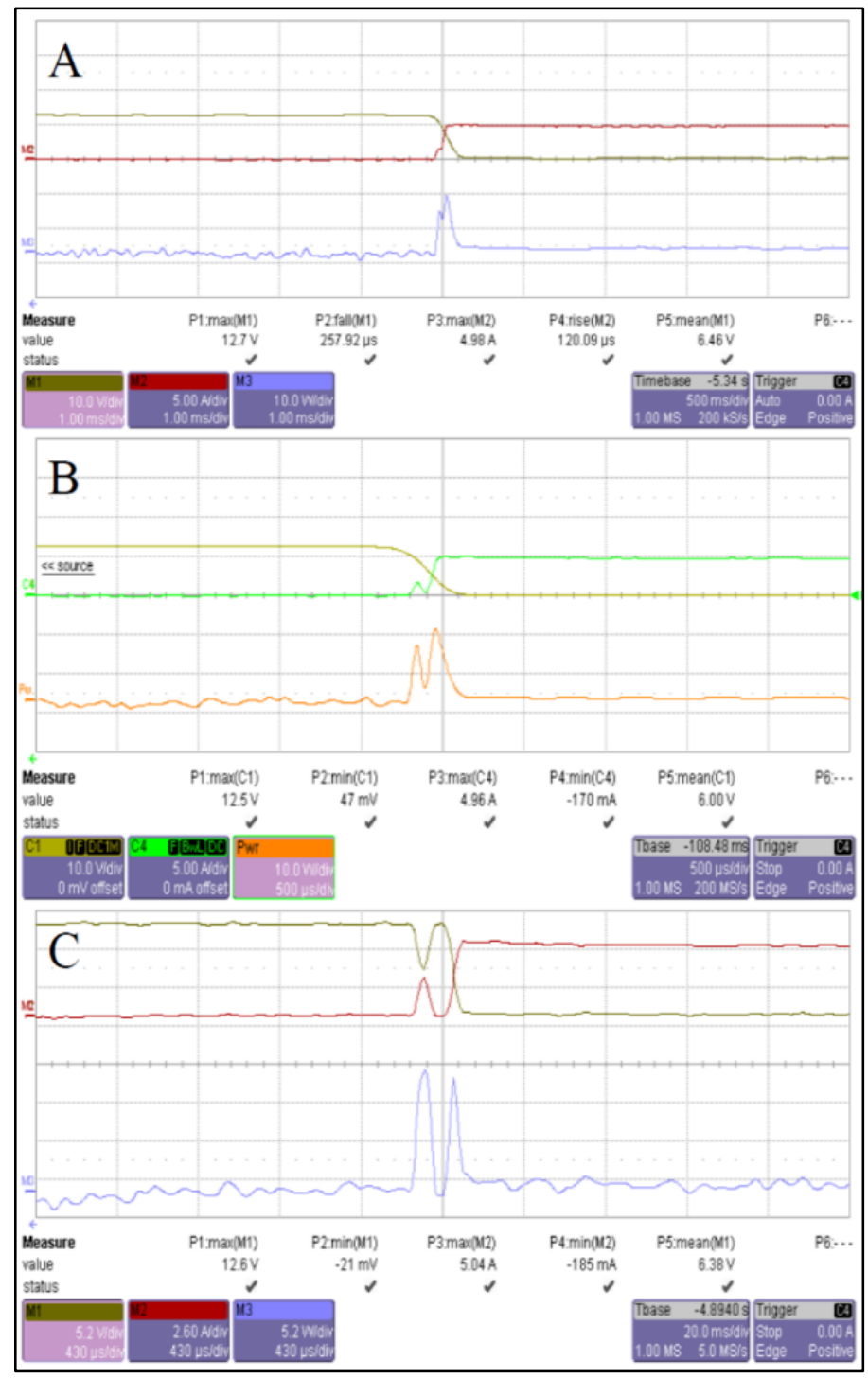

Şekil 6. A)10000 B)12000 C)20000 çevrim sonrasında iletime geçerken akım gerilim ve güç grafikleri.

Şekil 7'de verilen grafikte gerilim ve akımın yükseliş ve düşüş sürelerindeki artış verilmiştir. $\mathrm{Bu}$ artışı referans alarak anahtarlama sayısı arttıkça akım daha uzun sürelerde artmakta ve gerilim de tutarlı bir şekilde daha uzun sürede düşmektedir. Görüldüğü üzere anahtarın açık pozisyondan kapalı pozisyona geçmesinde belirgin bir gecikme söz konusu olmaktadır. Akımın düşüş süresi (Akım Tf) ise dikkate değer bir artış göstermemekle beraber eş zamanlı olarak gerçekleşen gerilimin artış süresi (Gerilim Tr) bir miktar artış göstermiştir. Akımın yükseliş süresi (Akım Tr) ve gerilimin düşüşs süresi (Gerilim Tf) de belirgin bir artış gözlemlenmektedir. Bu veriler bize çevrim sayısı arttıkça anahtarın kapanma olayı sırasında oluşan arkın süresinin arttığını vermektedir. Fakat bu verilere Şekil 5 'te verilen indüktif arklar dahil değildir. $\mathrm{Bu}$ sebeple Akım Tr-Tf ve Gerilim Tr-Tf sürelerinin tek başına referans alınması yanıltıcı sonuçlar verebilir.

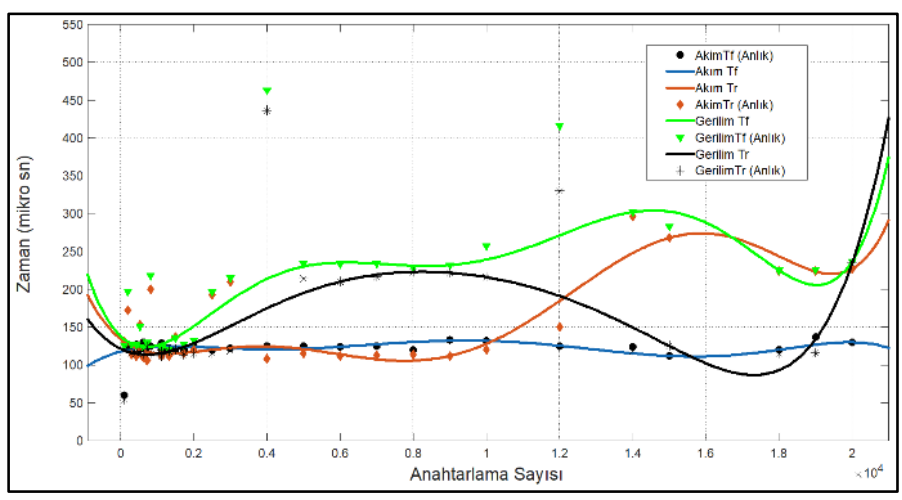

Şekil 7. Akım ve gerilim artış ve düşüş zamanlarının operasyon sayısına bağlı değişimi.

Şekil 9'da osiloskoptan elde edilen güç grafiklerinden kesim ve iletim esnasında oluşan ark enerjileri hesaplanmıştır. Bu veriler kullanılarak aşağıdaki grafik oluşturulmuştur. Buna göre anahtarlama sayısı arttıkça ark enerjileri ve süreleri artış göstermektedir. Bu ark enerjileri 10000 çevrime kadar artmakta ve sonrasında tekrar düşmektedir. İletim ve kesim sırasında olan arklardan bağımsız olarak kesim olayından $1.5 \mathrm{~ms}$ sonrasında gerçekleşen indüktif ark düzensiz aralıklarla gerçekleşmiş olup enerji artış grafiği iletim ve kesim sırasında gerçekleşen arklarla uyumludur. Bu ark olayında gerçekleşen erozyon katottan anoda taşınım şeklinde olmaktadır ve üç temel bileşenden meydana gelir: iyonlar, nötral buhar ve makro partiküller. İyon bombardımanı ile yüzeyden metal koparılması etkendir (Murzakaev, 2016; X. Zhou et al., 1994).

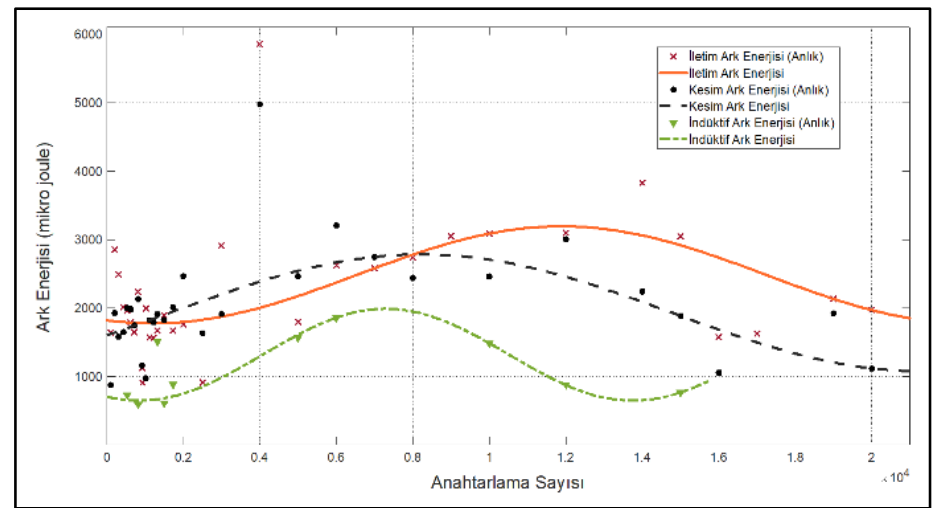

Şekil 8. Ark enerjilerinin çevrim sayısına göre değişimi.

\subsection{Yüzey Topografisi ve Hasar Analizi}

Elektrik ark erozyonu sonrasında yüzeyde gerçekleşen erozyon temassiz lazer optik profilometre (Nanovea PS50, USA) yardımıyla gerçekleştirilmiştir. Ark erozyonu testi sonrasında erozyonun gerçekleştiği bölgeler, malzeme birikiminin gerçekleştiği bölgeler ve taşınan hacim bilgileri elde edilmiştir. Topografi ve hasar analizinde özel bir yazılım olan Mountains ${ }^{\circledR}$ (surface imaging \& metrology software,FR) kullanılmıştır. Numunelerin kavislerinden kaynaklı lazer 1şını reseptöre dönmeyecek şekilde yansımalar oluşturmaktadır. $\mathrm{Bu}$ yansımalar sonucunda elde edilen görüntüde numunelerin kenarlarında ölçümlenememiş noktalar oluşmakta ve program bu bölgeleri bize boşluk olarak göstermektedir. Deformasyon bölgesinden uzakta olması ve herhangi bir etkiye sahip olmamasından kaynaklı olarak anlamlı analizi kolaylaştırmak adına numune kenarlarında bozuk ölçümleri dışarda bırakacak şekilde bir alan çıkarımı yapılmıştır. Numunenin ölçüm tablasına yerleştirilmesinden kaynaklı sahip olduğu eğim ise 
kademelendirme (leveling) komutu ile giderilmiştir. Yapılan analizlerde deformasyon bölgeleri tespit edilmesinin ardından daha belirgin bir ölçüm adına pik ve çukur ölçümleri yapılmadan önce sabit kontakların görüntüsüne "dilation" filtresi hareketleri kontakların görüntüsüne "erosion" filtresi uygulanmıștır. Bu filtreler Mountain Labs programının sahip olduğu filtreleme seçenekleri oluşturulan sanal görüntü üzerinde daha doğru gözlemler ve analizler yapılması için hazırlanmış modüllerdir.

\subsubsection{OS ve $0 \mathrm{H}$ numunelerinin incelenmesi}

Şekil 9 ve 10'da erozyon deneyine sokulmamış numunelerin yüzeyleri görülmektedir. Beklenildiği üzere herhangi bir deformasyon barındırmamaktadır. Üretimden kaynaklanan önemsenmeyecek küçük hatalar dışında pürüzlülük oranı son derece düşük yüzeyler gözlemlenmiştir.

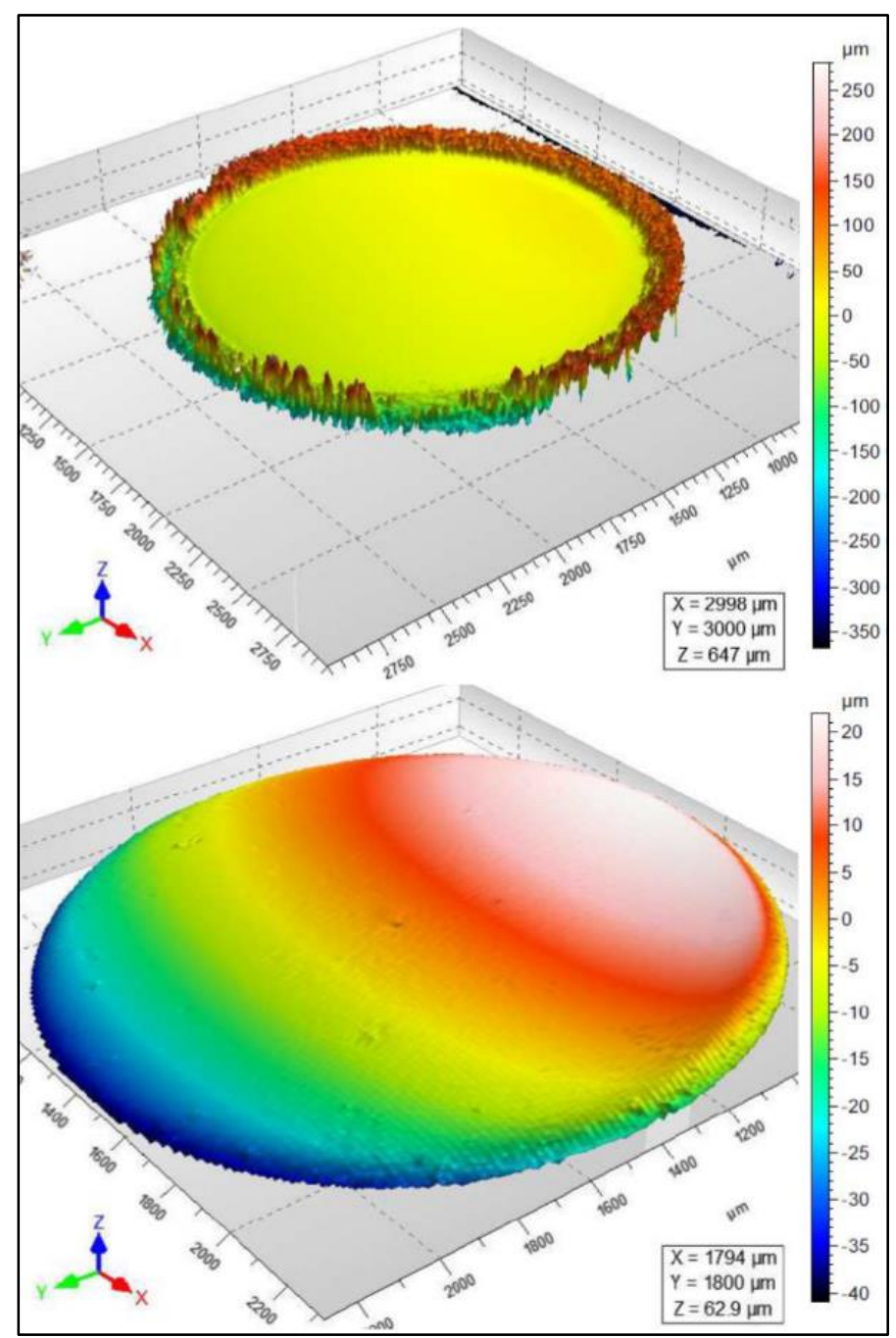

Şekil 9. 0S'e ait profilometre görüntüsü.

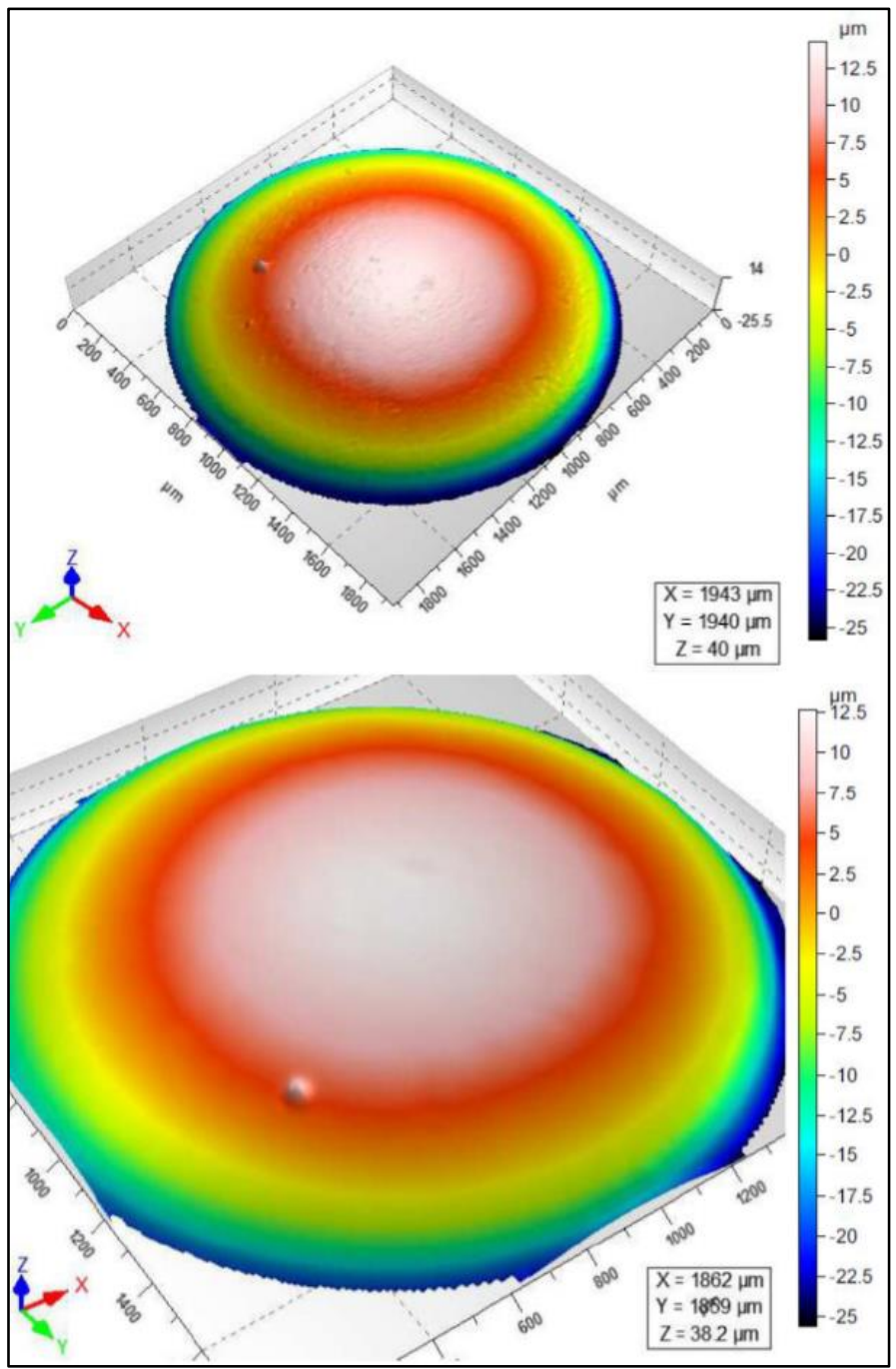

Şekil 10. 0H'a ait profilometre görüntüsü.

\subsubsection{S Numunesinin incelenmesi}

Şekilde görüldüğü üzere katotta yaklaşık $0.1713 \mathrm{~mm}^{2}$ lik bir alanda erozyon birikmesi gerçekleşmiştir. Bu birikmenin Şekil 11-B de hesaplanan hacmi $781566 \mu \mathrm{m}^{3}$ ve maksimum yükseklik $12.63 \mu \mathrm{m}$ olarak ölçülmüştür. Oluşan birikme homojen bir birikme şeklinde gerçekleşmemiş olup bir tepe şeklinde yoğunlaşmıştır. Birikmenin çevresinde düşük miktarda erozyon da gözlemlenmiştir. 


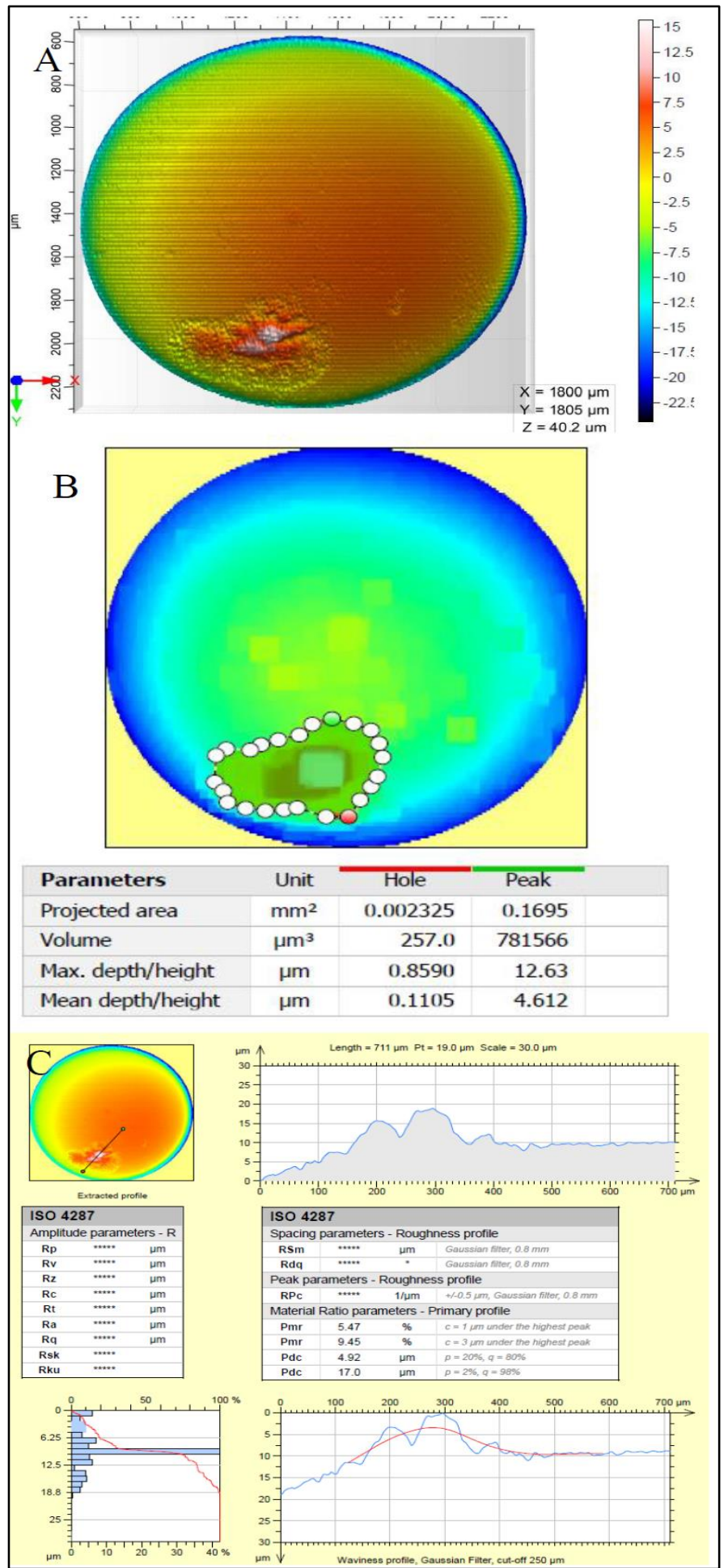

Şekil 11. 5S'e ait yüzey analizleri. A) Genel görünüm. B) pik ve çukur ölçümü. C) çizgi grafik yükseklik ölçümü.

\subsubsection{S Numunesinin incelenmesi}

Yapılan ölçümler sonucunda 10000 çevrim sonucunda $0.1523 \mathrm{~mm}^{2}$ lik bir alanda deformasyon gözlemlenmektedir. $874196 \mu^{3}$ hacminde malzeme birikmesi söz konusudur. Ölçülen maksimum yükseklik değeri $15.04 \mu \mathrm{m}$ yüksekliğindedir.

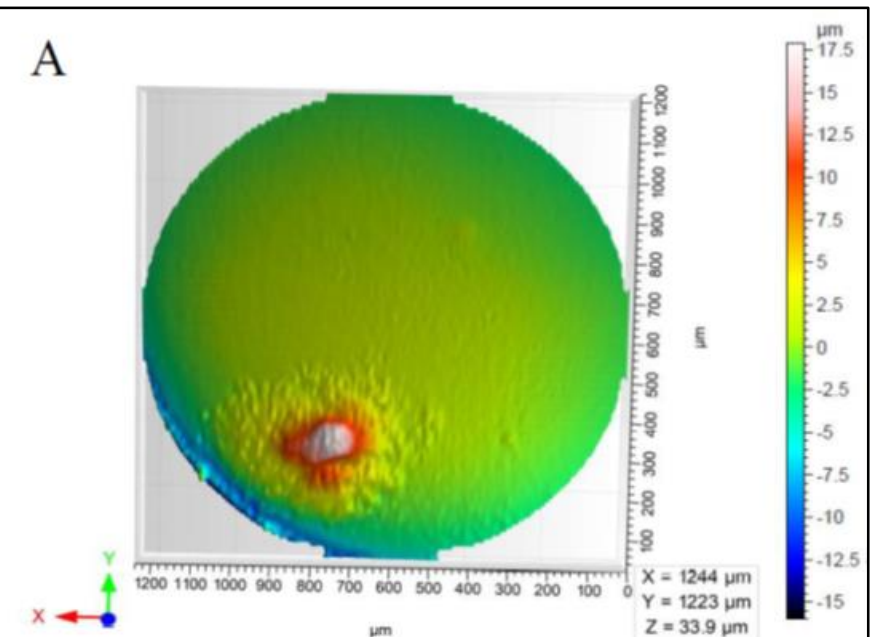

B

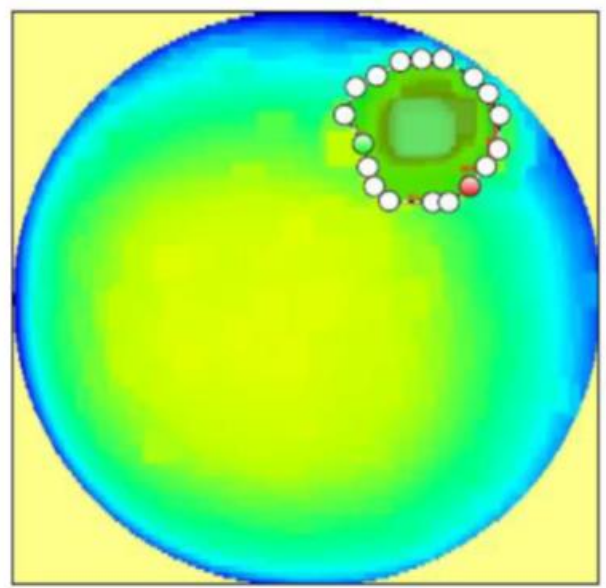

\begin{tabular}{lcrrr}
\hline Parameters & Unit & Hole & Peak \\
\cline { 3 - 4 } Projected area & $\mathrm{mm}^{2}$ & 0.0057 & 0.1466 \\
\hline Volume & $\mu \mathrm{m}^{3}$ & 1052 & 874196 \\
\hline Max. depth/height & $\mu \mathrm{m}$ & 0.9783 & 15.04 \\
\hline Mean depth/height & $\mu \mathrm{m}$ & 0.1846 & 5.962 \\
\hline
\end{tabular}
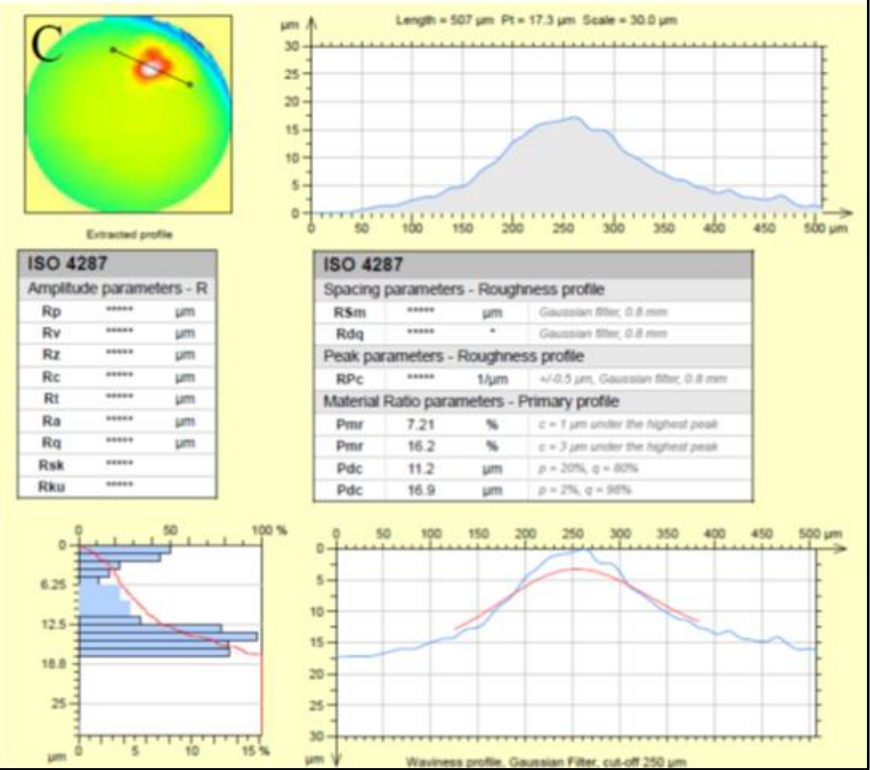

Şekil 12. 10S'e ait yüzey analizleri. A) Genel görünüm. B) pik ve çukur ölçümü. C) çizgi grafik yükseklik ölçümü. 


\subsubsection{S Numunesinin incelenmesi}

20000 anahtarlamanın sonunda birikme $0.2292 \mathrm{~mm}^{2}$ alana yayılarak çok daha geniş bir alanda erozyon gözlemlenmektedir. Özgün şekilde birbirinden tam olarak ayrı iki tepeleşme gözlemlenmektedir. Gözlemlenen maksimum yükseklik 26.93 $\mu \mathrm{m}$ ve toplam biriken hacim $1928121 \mu \mathrm{m}^{3}$ biriken malzemelerin oluşturduğu yüzey alanı ise ile beklenildiği gibi diğer numunelerden daha fazladir.

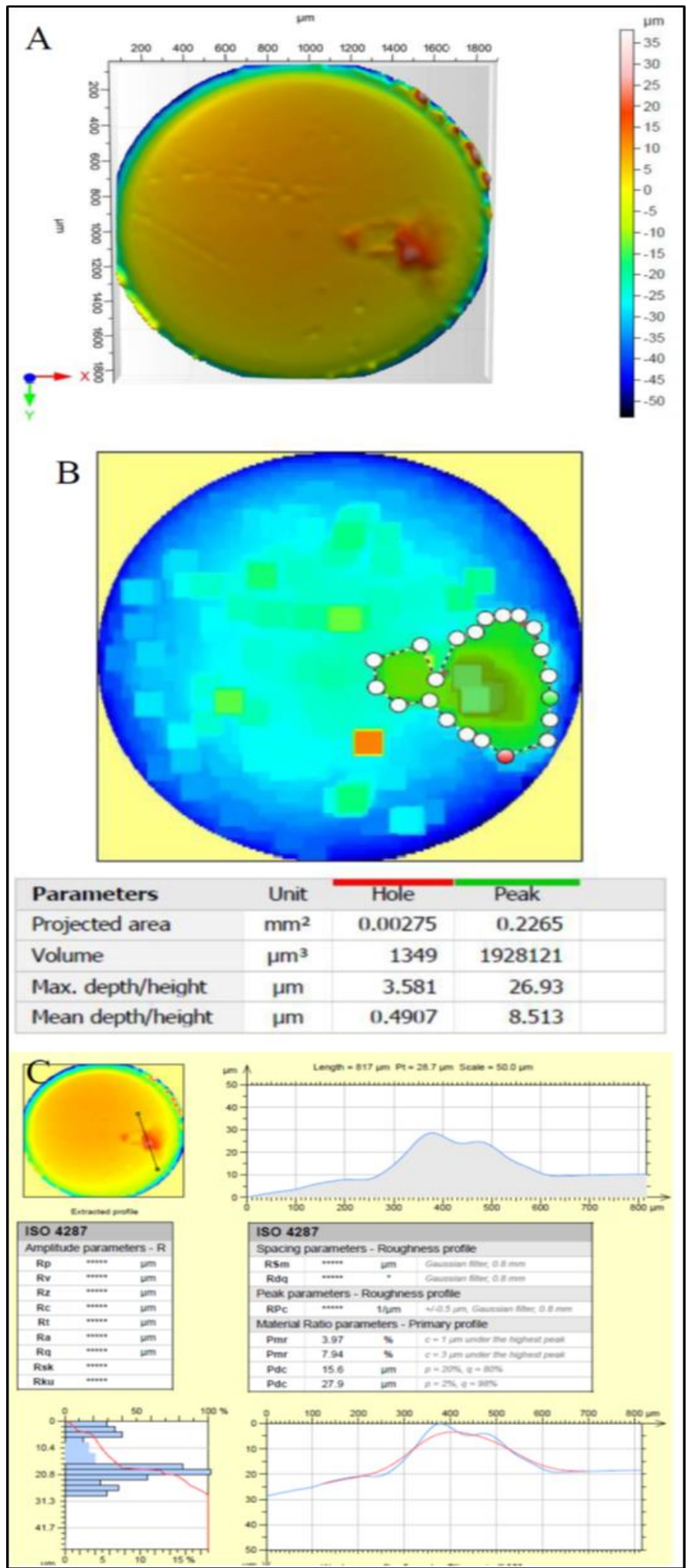

Şekil 13. 20S'e ait yüzey analizleri. A) Genel görünüm. B) pik ve çukur ölçümü. C) çizgi grafik yükseklik ölçümü.

\subsubsection{H Numunesinin incelenmesi}

Şekilde görüldüğü üzere 5000 anahtarlama sonrasında $5 \mathrm{H}$ yüzeyinde yaklaşık $0.2271 \mathrm{~mm}^{2}$ 'lik bir alanda deformasyon gerçekleşmiştir. $\mathrm{Bu}$ deformasyonun sırasında malzeme kaybının hacmi yaklaşık $782656 \mu^{3}$ ve maksimum derinlik $11.05 \mu \mathrm{m}$ olarak ölçümlenmiştir.

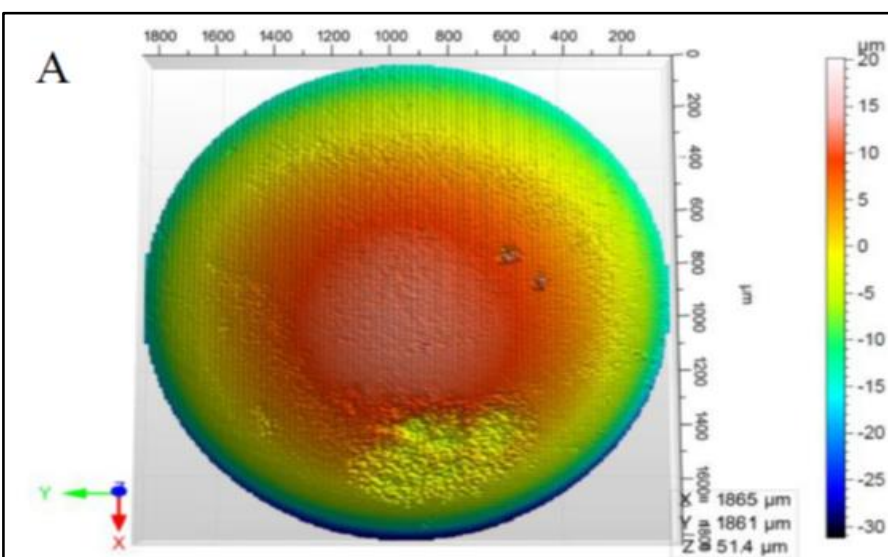

$\mathrm{B}$

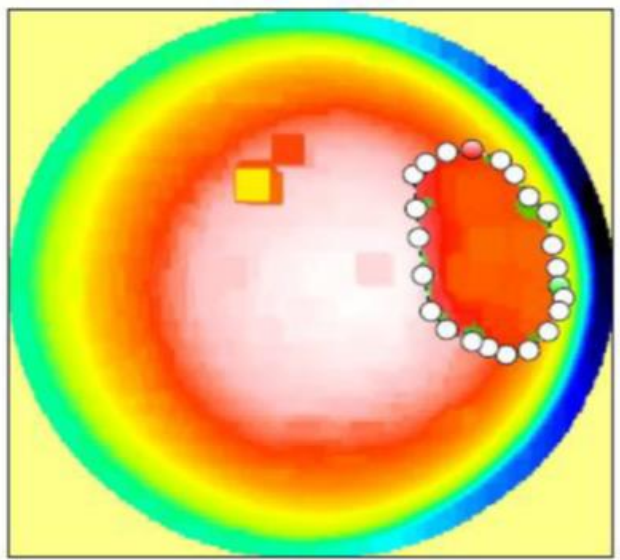

\begin{tabular}{|l|r|r|r|}
\cline { 3 - 4 } Parameters & Unit & \multicolumn{1}{c}{ Hole } & \multicolumn{1}{c}{ Peak } \\
\hline Projected area & $\mathrm{mm}^{2}$ & 0.2064 & 0.02068 \\
\hline Volume & $\mu \mathrm{m}^{3}$ & 782656 & 10110 \\
\hline Max. depth/height & $\mu \mathrm{m}$ & 11.05 & 2.535 \\
\hline Mean depth/height & $\mu \mathrm{m}$ & 3.792 & 0.4888 \\
\hline
\end{tabular}

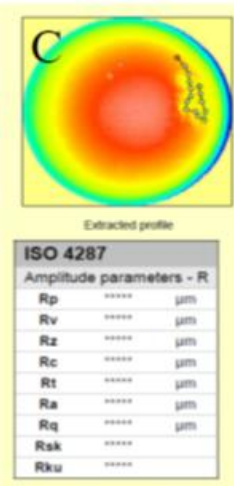

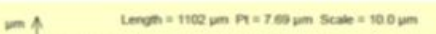
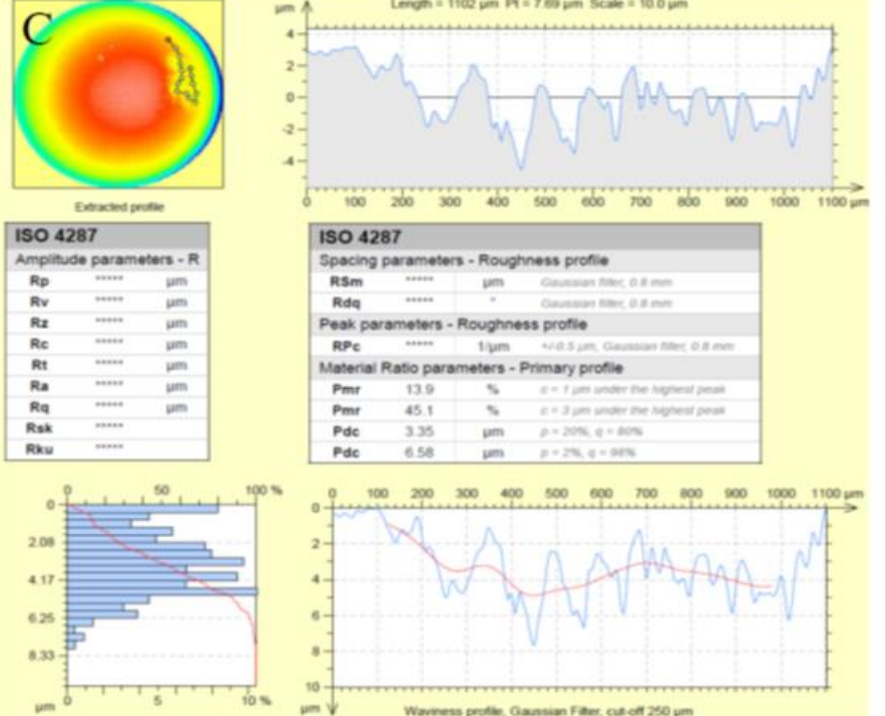

Şekil 14. 5H'a ait yüzey analizleri. A) Genel görünüm. B) pik ve çukur ölçümü. C) çizgi grafik yükseklik ölçümü. 


\subsubsection{H Numunesinin incelenmesi}

Şekilde görüldüğü üzere 10000 anahtarlama sonrasında $10 \mathrm{H}$ yüzeyinde yaklaşı $0,1818 \mu \mathrm{m}^{2}$ lik bir alanda deformasyon gerçekleşmiştir. Bu deformasyonun sırasında malzeme kaybının hacmi yaklaşık $880164 \mu \mathrm{m}^{3}$ ve maksimum derinlik $17.35 \mu \mathrm{m}$ olarak ölçümlenmiştir.

\section{A}

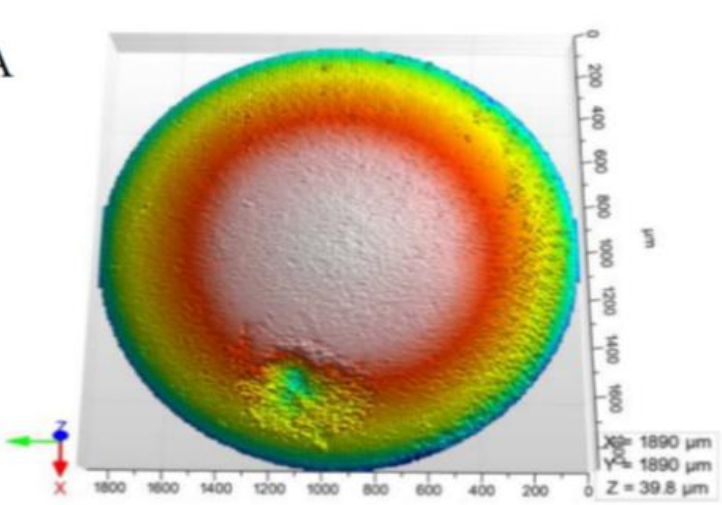

B

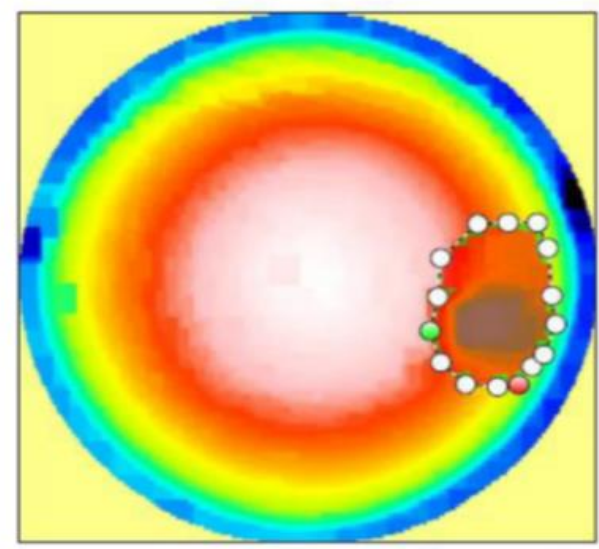

\begin{tabular}{lcrrr}
\hline Parameters & Unit & Hole & \multicolumn{1}{c}{ Peak } \\
\cline { 4 - 5 } Projected area & $\mathrm{mm}^{2}$ & 0.1604 & 0.02139 \\
\hline Volume & $\mu \mathrm{m}^{3}$ & 880164 & 10784 \\
\hline Max. depth/height & $\mu \mathrm{m}$ & 17.35 & 1.531 \\
\hline Mean depth/height & $\mu \mathrm{m}$ & 5.487 & 0.5041 \\
\hline
\end{tabular}
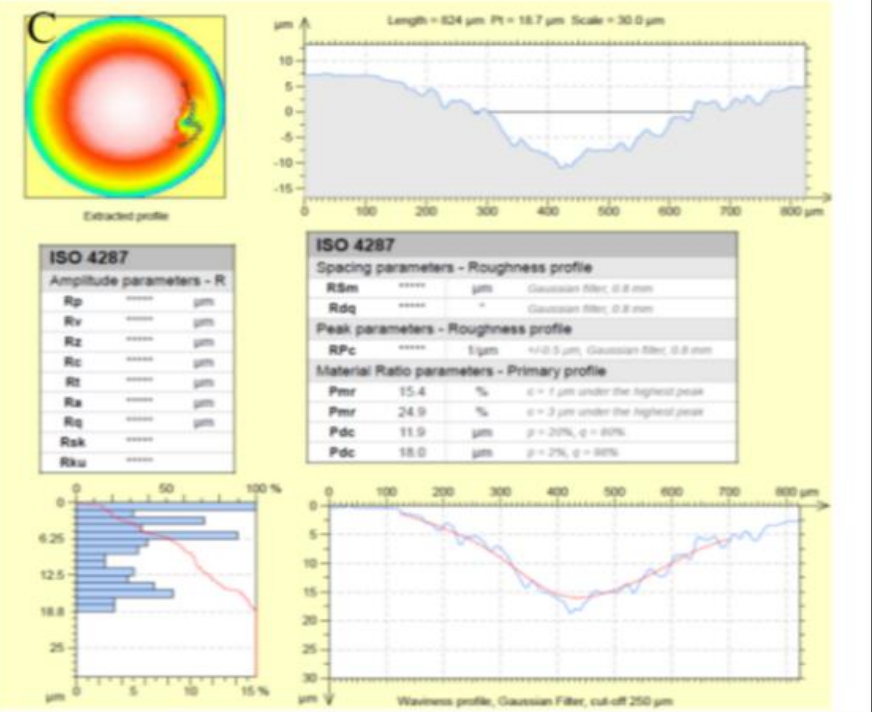

Şekil 15. 10H' a ait yüzey analizleri. A) Genel görünüm. B) pik ve çukur ölçümü. C) çizgi grafik yükseklik ölçümü.

\subsubsection{H Numunesinin incelenmesi}

Şekilde görüldüğü üzere 20000 anahtarlama sonrasında $20 \mathrm{H}$ yüzeyinde yaklaşı $0.2528 \mathrm{~mm}^{2}$ lik bir alanda deformasyon gerçekleşmiştir. Bu deformasyonun sırasında malzeme kaybının hacmi yaklaşık $1167886 \mu \mathrm{m}^{3}$ ve maksimum derinlik $21.5 \mu \mathrm{m}$ olarak ölçümlenmiştir.

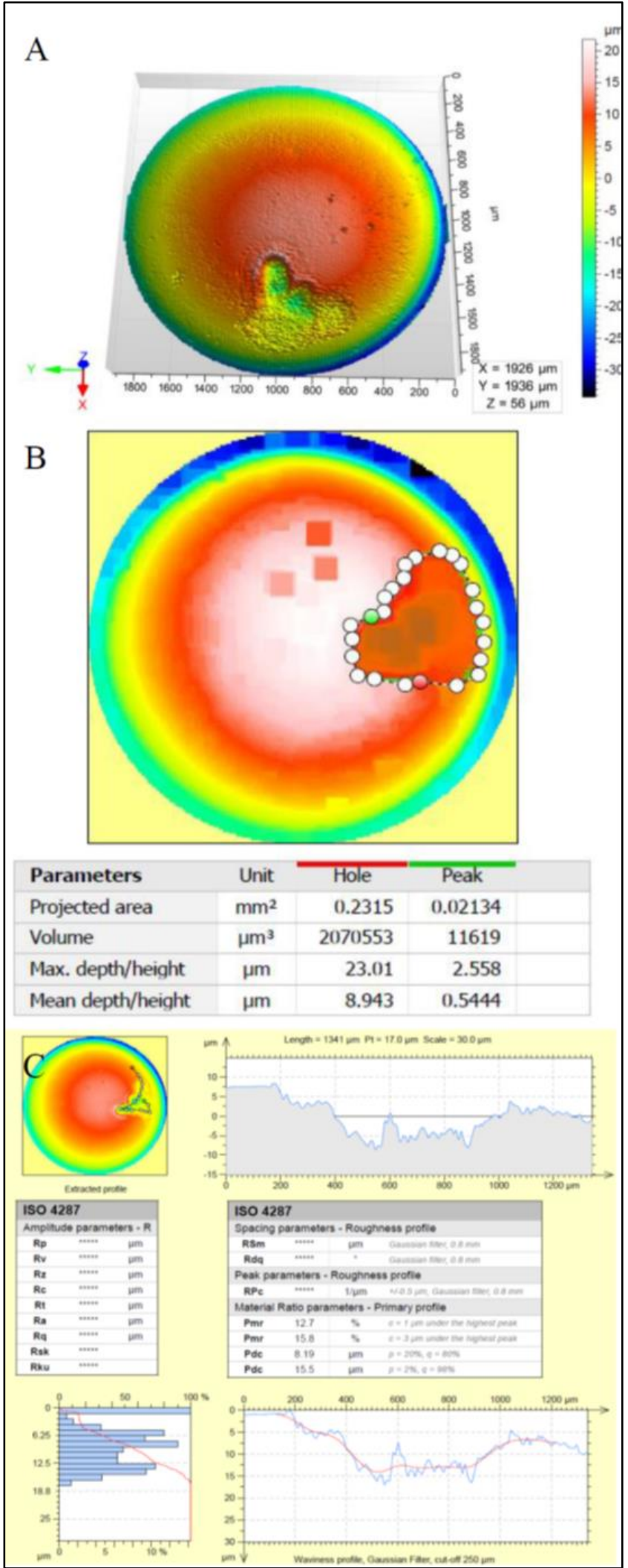

Şekil 16. 20H'a ait yüzey analizleri. A) Genel görünüm. B) pik ve çukur ölçümü. C) çizgi grafik yükseklik ölçümü. 


\section{Araştırma Sonuçları ve Tartışma}

\subsection{Hacimce Erozyon Miktarının Karşılaştırılması.}

Tablo 1 ve 2'de numunelere ait veriler listelenmiştir. Görüldüğü üzere 5 bin ve 10 bin çevrimler arasında nispeten düşük oranlarda hacim değişsimi vardır. Fakat 20 bin anahtarlamada bu hacim değişimi beklenilen şekilde 10 bin anahtarlamanın 2 katı'nın üzerinde oranında gerçekleşmiştir. Erozyon yüzey alanındaki artış ise hacimce değişimle doğrusallık göstermemektedir.

Tablo 1. Sabit kontağa ait erozyon verileri.

\begin{tabular}{l|c|c|c}
\hline Numune & Erozyon hacmi $\left(\boldsymbol{\mu m}^{\mathbf{3}} \mathbf{x} \mathbf{1 0}^{\mathbf{4}}\right)$ & Erozyon alanı $\left(\mathbf{m m}^{2}\right)$ & Yükseklik max $(\boldsymbol{\mu m})$ \\
\hline $5 S$ & 78,16 & 0.17 & 12.63 \\
\hline $10 S$ & 87,42 & 0.15 & 15,04 \\
\hline $20 S$ & 19,28 & 0.23 & 26.93 \\
\hline
\end{tabular}

Tablo 2. Hareketli kontağa ait erozyon verileri.

\begin{tabular}{l|l|l|l}
\hline Numune & Erozyon hacmi $\left(\boldsymbol{\mu m}^{\mathbf{3}} \mathbf{x} \mathbf{1 0}^{\mathbf{4}}\right)$ & Erozyon alani $\left(\mathbf{m m}^{\mathbf{2}}\right)$ & Derinlik $\mathbf{m a x}(\boldsymbol{\mu \mathbf { m }})$ \\
\hline $50 H$ & 78,27 & 0.23 & 11.05 \\
\hline $10 H$ & 88,02 & 0,18 & 17.35 \\
\hline $20 H$ & 20,71 & 0.25 & 23.01 \\
\hline
\end{tabular}

Şekil 17'de birbiri ile eş olan kontaklardan kaybedilen hacim ve biriken hacim verileri karşılaştırılıp bir grafik haline getirilmiştir. Kurulan devrede hareketli kontaklarımız anot; sabit kontaklarımız ise katot konumundadır. 5 bin, 10 bin ve 20 bin çevrim olmak üzere kontak çiftlerinin hacim değişimi grafiği oluşturulmuştur. 5 bin ve 10 bin çevrimde biriken ve erozyona uğrayan malzeme miktarlarının farkı çok küçük olurken; 20 bin çevrimde bu fark bir sıçrama göstermiştir.

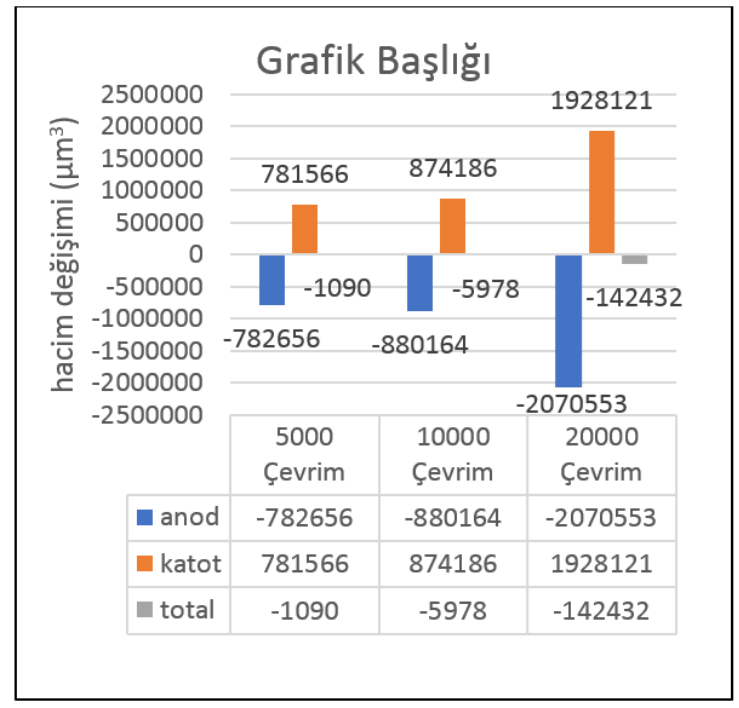

Şekil 17. Çevrim sayısına göre hacim değişimleri. e-ISSN: 2148-2683

\subsection{Elektriksel Veriler ile Erozyon Karakteristiğinin Yorumlanması.}

Osiloskop verileri incelendiğinde kontaktörlerde iletime geçerken ve iletimi keserken ark oluştuğu gözlemlenmiştir. Fakat yapılan araştırmalara göre malzeme taşınımının genellikle kontaktörler kapanırken değil açılırken yaşandığı ortaya konulmuştur. Bu iki ark olayının yanı sıra düzensiz aralıklarda kontaktörler açıldıktan $1.5 \mathrm{~ms}$ sonrasında ark olayı gözlemlenmiştir. $\mathrm{Bu}$ ark olayının gerçekleşme şekli birçok etmene bağlı olsa da gerçekleşme sebebi devre rezistif olarak hazırlansa da içinde barındırdığı indüktif yük bileşenidir. İndüktif ark oluşumu katottan anoda malzeme taşınmasını sağlayan bir erozyon mekanizmasına sahiptir. $\mathrm{Bu}$ erozyon mekanizmasında kontaklar arası mesafenin artışı malzeme taşınım oranını arttırmakta ve kullanılandan daha yüksek akımgerilim değerlerine ihtiyacı vardır (Jemaa et al., 1998). Düşük akım değerlerinde yaklaşık olarak $8 \mathrm{~mm}$ gibi bir kontak açıklığında katottan anoda gerçekleşen bu ark erozyonu dikkate alınabilecek bir birikim oluşturamamaktadır. Erozyonun varlığı $5 \mathrm{~S}$ numunesinin yüzeyinde gözlemlenebilmiştir.

Deformasyon yüzeyinin iç kısımlarında anahtarlamalar sırasında oluşan rezistif ark sonucu birikme gözlemlenirken tepe oluşumunun etrafında pürüzlülüğü yüksek ve birkaç mikron derinliğinde çukurlaşmalar görülmektedir. $\mathrm{Bu}$ durum totalde gerçekleşen malzeme birikiminin önüne geçebilecek boyutlarda değildir. Tablo 1 ve 2 de verilen erozyon alanı değerleri 
incelendiğinde 5 bin çevrim uygulanan numunelerin erozyona maruz kalan alanları 10 bin çevrim uygulanan numunelerden beklenmedik şekilde daha fazla olduğu görülmektedir. $\mathrm{Bu}$ numunelerin erozyon hacimlerinde ise beklenilen şekilde 10 bin çevrimde daha fazla taşınım gözlemlenmiştir. $\mathrm{Bu}$ farklılığın sebebi yine düzensiz aralıklarla gerçekleşen indüktif ark oluşumu ve bundan kaynaklı daha geniş yüzey alanlarının deforme olmasıdır. Düşük akım ve gerilim şiddetlerinde kütle taşınımına etki eden temel mekanizma anot erozyonu olsa da deformasyon gözlemlenen yüzeyin genişliğine her iki erozyon mekanizması da etki sahibidir.

Şekil 17'de verilen grafikte görüldüğü gibi malzeme taşınımı anottan katoda gerçekleşmiştir ve net kayıp miktarı 20 bin anahtarlama sonunda yaklaşık olarak $1.4 \mu \mathrm{g}$ olacak kadar küçüktür. $\mathrm{Bu}$ kayıp miktarı göz önünde bulundurulduğunda kontaktörler malzeme taşınımı neredeyse kayıpsız şekilde gerçekleşmiştir. Fakat malzeme kaybının lineer bir artış göstermediğini göz önünde bulundurursak daha yüksek çevrimlerinde ciddi kayıplar söz konusu olabilir.

Şekil 6'da osiloskop grafiklerine bakıldığında belirli bir anahtarlama sayısından sonra devrenin kapanmasında grafiklerdeki piklerde çiftlenme devrenin iletim konumuna geçişinde aksaklık yaşaması anlamına gelmektedir. Bu oluşuma benzer şekilde çeşitli uygulamalarda "bouncing" etkisinden bahsedilmiştir. Fakat "bouncing" olayında kontaktörleri tutan kirişlerin elastik hareketinin etkisi vardır. Sonuç olarak ark oluşumuna etki etse de olayın gerçekleşme sebebi mekanik özelliklerden kaynaklanmaktadır (Swingler \& McBride John W., 2008),(Hwang et al., 2020),(Zhu et al., 2017). Buna karşın çalışmamızda bu çatallanma durumu 10 bin çevrimden sonra gözlemlenmeye başlanmıştır. Şekil 16 incelendiğinde erozyon bölgesinde çukurlaşmanın olduğu yerin kenarlarında bir yükselti artışı gözlemlenmektedir. Bu durum plastik deformasyon veya sıv1 metalin sıçraması ile gerçekleşebilir. Erozyon bölgeleri incelendiğinde ise birbirinden belirgin bir şekilde ayrı iki büyük çukur görülmektedir. $\mathrm{Bu}$ iki ayrı çukurun oluşumu iki farklı noktada temas sonucu ergimelerin gerçekleştiği anlamına gelir. Diğer numunelere ait şekil 11, 12, 14 ve 15 incelendiğinde ise erozyonun tek bir merkez etrafında yoğunlaştığı gözlemlenebilir. $\mathrm{Bu}$ veriler 1şı ğında 20 bin anahtarlamanın gerçekleşmesi sürecinde $20 \mathrm{H}$ numunesinde önce tek bir çukur oluştuğu ve $20 \mathrm{~S}$ numunesinde ise tek bir tepe oluştuğu daha sonra ise bu topografik bozulma belli bir seviyeye gelince dinamik temas noktalarının değişerek yakın çevrelerde ikincil bir temas alanı oluşması söz konusudur. İletim grafiklerinde çift pik oluşumunun anahtarlama sayısının ilerlemesi ile belirginleşmesi ve şiddetlenmesinin bu deformasyon süreci ile ilgili olduğu çıkarımı yapılmıştır.

Şekil 8'de ark enerjisinin 10 bin çevrimden sonra tekrar azalmaya başlamasının sebebi de yüzeyde gerçekleşen bu bozulma sebebiyle yeni temas noktalarından iletime geçilmesi ve daha az deforme olmuş bu yüzeylerin elektrik iletiminin, sıv1 metal havuzlarının ve ark erozyonu olayının yeni bölgesi olmasından kaynaklı olduğu çıkarımı yapılmaktadır.

\section{Sonuç}

Yapılan bazı araştırmalar ark süresi ve ark enerjisi arasında doğrusal bir bağ olduğunu ortaya koymuştur (Zhu et al., 2017),(Hu et al., 2016). Bu yaklaşım oluşan ark şiddetinin sabit olduğu durumlarda doğrudur fakat bu çalışmada ark enerjisinin hesaplanması sırasında ark şiddetinin stabil olmadığı ve e-ISSN: 2148-2683 değişkenlik gösterdiği hatta ark karakteristiğinin bile stabil olmadığı gözlemlenmiştir. Yapılan hesaplamalarda daha kısa ark sürelerinde daha yüksek akım ve voltaj değerlerinin olduğu kimi durumlarda süre düşük olsa da ark enerjisinin yüksek olduğu durumlar gözlemlenmiştir. $\mathrm{Bu}$ çalışma sırasında elde edilen bulgular şu şekildedir:

1. 12 VDC 5A rezistif bir devrede kullanılan dirençlerin indüktif bileşeninden kaynaklı tek çeşit bir ark oluşumu ve ark erozyonu gözlemlenmemektedir. Buna karşın net erozyon anottan katota doğru gerçekleşmektedir.

2. Kullanılan numunelerde 10 bin çevrime kadar oluşan deformasyon elektrik verileri üzerinden gözlemlenemezken 10 bin çevrim ve sonrasında anahtarın kapanması ve iletime geçmesi sırasında grafiklerde belirgin bir farklılık oluşmaktadır. $\mathrm{Bu}$ grafikler incelenerek numunenin temas yüzeyi üzerindeki deformasyon hakkında fikir sahibi olunabilir.

3. 10 bin çevrime kadar artan ark enerjisinin sonrasında düşüşe geçmesinin sebebi malzeme yüzeyinde deformasyonlar sonucunda dinamik temas noktalarının değişerek ark erozyonunun deforme olmamış veya daha az deforme olmuş yeni bölgelere kayması olabileceği değerlendirilmiştir.

\section{Kaynakça}

Abbaoui, M., Lefort, A., Sallais, D., \& Jemaa, N. B. (2006). Theoretical and experimental determination of erosion rate due to arcing in electrical contacts. Electrical Contacts 2006. Proceedings of the 52nd IEEE Holm Conference on Electrical Contacts, 103-109. https://doi.org/10.1109/HOLM.2006.284072

Bıyık, S. (2015). TiO2 Takviyesi İçeren AgSnO2 Esaslı Elektrik Kontak Malzemelerinin Toz Metalurjisi Yöntemiyle Üretimi ve Ark-Erozyon Davranışlarının İncelenmesi. In Karadeniz Teknik Üniversitesi Fen Bilimleri Enstitüsü, Makine Mühendisliği Anabilim Dall.

Cui, X., Zhou, X., Zhai, G., \& Peng, X. (2016). Evaporation Erosion during the Relay Contact Breaking Process Based on a Simplified Arc Model. Plasma Science and Technology, 18(5), 512-519. https://doi.org/10.1088/1009-0630/18/5/12

Hu, P., Hu, B. L., Wang, K. S., Yang, F., Song, R., Yu, Z. T., Wang, Q., Cao, W. C., Liu, D. X., An, G., Guo, L., \& Yu, H. (2016). Arc erosion behavior of La-doping titaniumzirconium-molybdenum alloy. Journal of Alloys and Compounds, 685(3), 465-470. https://doi.org/10.1016/j.jallcom.2016.05.328

Hwang, S., Hwang, D., Baek, H., \& Shin, C. (2020). Effect of Copper-Based Spring Alloy Selection on Arc Erosion of Electrical Contacts in a Miniature Electrical Switch. Metals and Materials International, 0123456789. https://doi.org/10.1007/s12540-019-00602-x

Jemaa, N. Ben, Morin, L., Benhenda, S., \& Nedelec, L. (1998). Anodic to cathodic arc transition according to break arc lengthening. IEEE Transactions on Components, Packaging, and Manufacturing Technology. Part A, 21(4), 599-602. https://doi.org/10.1109/95.740051

Jing, W., Jianwen, W., \& Liying, Z. (2011). Arc behavior of intermediate-frequency vacuum arc on axial magnetic field contacts. IEEE Transactions on Plasma Science, 3966 PART 1), 1336-1343. https://doi.org/10.1109/TPS.2011.2119496

Kharin, S. N., Nouri, H., \& Miedzinsky, B. (2015). A comparative study of arc erosion at frequencies ranging 50$1000 \mathrm{~Hz}$. Electrical Contacts, Proceedings of the Annual 
Holm Conference on Electrical Contacts, 2015-

Febru(February).

https://doi.org/10.1109/HOLM.2014.7031048

Lin, Z., Fan, S., Liu, M., Liu, S., Li, J. G., Li, J., Xie, M., Chen, J., \& Sun, X. (2019). Excellent anti-arc erosion performance and corresponding mechanisms of a nickel-belt-reinforced silver-based electrical contact material. Journal of Alloys and Compounds, 788, 163-171. https://doi.org/10.1016/j.jallcom.2019.02.085

Liying, Z., Jianwen, W., \& Xueming, Z. (2013). Arc movement of intermediate-frequency vacuum Arc on TMF contacts. IEEE Transactions on Power Delivery, 28(4), 2014-2021. https://doi.org/10.1109/TPWRD.2013.2272590

Murzakaev, A. M. (2016). Erosion rate in a vacuum arc and in a gas arc at threshold currents. Proceedings - International Symposium on Discharges and Electrical Insulation in Vacuum, ISDEIV, 2016-Novem. https://doi.org/10.1109/DEIV.2016.7748757

Mützel, T., \& Niederreuther, R. (2012). Contact material combinations for high performance switching devices. Electrical Contacts, Proceedings of the Annual Holm Conference on Electrical Contacts, 179-184. https://doi.org/10.1109/HOLM.2012.6336602

Rong, M., Ma, Q., Wu, Y., Xu, T., \& Murphy, A. B. (2009). The influence of electrode erosion on the air arc in a low-voltage circuit breaker. Journal of Applied Physics, 106(2). https://doi.org/10.1063/1.3176983

Swingler, J., \& McBride John W., J. W. (2008). Micro-arcing and arc erosion minimization using a DC hybrid switching device. IEEE Transactions on Components and Packaging Technologies, $31(2 \quad$ SPEC. ISS.), 425-430. https://doi.org/10.1109/TCAPT.2008.921640

Tian, Y., Wang, Z., Jiang, Y., Ma, H., Liu, Z., Geng, Y., \& Wang, J. (2016). Simulation of surface erosion of anode under high-current vacuum arcs. Proceedings - International Symposium on Discharges and Electrical Insulation in Vacuum, ISDEIV, 2016-Novem, 3-6. https://doi.org/10.1109/DEIV.2016.7748744

Wu, C., Yi, D., Weng, W., Li, S., Zhou, J., \& Zheng, F. (2015). Arc erosion behavior of $\mathrm{Ag} / \mathrm{Ni}$ electrical contact materials. Materials and Design, 85, 511-519. https://doi.org/10.1016/j.matdes.2015.06.142

Zhou, X., Heberlein, J., \& Pfender, E. (1994). Theoretical study of factors influencing arc erosion of cathode. Electrical Contacts, Proceedings of the Annual Holm Conference on Electrical Contacts, 1994-march(1), 107-112. https://doi.org/10.1109/HOLM.1992.246932

Zhou, Xue, Cui, X., Chen, M., \& Zhai, G. (2015). Evaporation Erosion of Contacts under Static Arc by Gas Dynamics and Molten Pool Simulation. IEEE Transactions on Plasma Science, 43(12), 4149-4160. https://doi.org/10.1109/TPS.2015.2497720

Zhu, S., Liu, Y., Tian, B., Zhang, Y., \& Song, K. (2017). Arc erosion behavior and mechanism of $\mathrm{Cu} / \mathrm{Cr} 20$ electrical contact material. Vacuum, 143, 129-137. https://doi.org/10.1016/j.vacuum.2017.06.002 